\title{
Primary Leiomyosarcoma of ParatesticularRegion: Very Good Response to Chemotherapy for Intraabdominal Metastases
}

\section{Paratestiküler Bölgenin Primer Leiomyosarkomu: Karın İçi Metastazlar İçin Verilen Kemoterapiye Çok İyi Yanıt}

\author{
Ayşe Gök Durnalı ${ }^{1}$, Necati Alkış ${ }^{1}$, Raziye Yazıcı ${ }^{2}$, Kaan Helvacı ${ }^{1}$, Murat Vural ${ }^{3}$, Berna Öksüzoğlu ${ }^{1}$ \\ ${ }^{1}$ Dr. A. Y. Ankara Onkoloji Eğitim Ve Araştırma Hastanesi, Tıbbi Onkoloji Kliniği, Ankara, Türkiye \\ ${ }^{2}$ Konya Eğitim Ve Araştırma Hastanesi, Nefroloji Kliniği, Konya, Türkiye \\ ${ }^{3}$ Ankara Numune Eğitim Ve Araştırma Hastanesi, Radyoloji Kliniği, Ankara, Türkiye
}

Dergiye Ulaşma Tarihi:27.02.2016 Dergiye Kabul Tarihi:27.03.2016 Doi: 10.5505/aot.2015.76588

\section{ÖZET}

Skrotal leiomyosarkoma nadiren görülür ve paratestiküler veya intratestiküler olabilmektedir. İki y1l önce paratestiküler leiomyosarkoma nedeniyle opere edilmiş olan 18 yaşında erkek hasta rezeke edilemeyen intraabdominal metastazlarla bölümümüze başvurdu. Kombinasyon kemoterapi rejimen (doksorubisin ve mesna korumasıyla birlikte ifosfamid) başlandı ve 6 uygulama sonrasında çok iyi parsiyel regresyon sağlandı. Bizim olgumuz, paratestiküler leiomyosarkomalı hastaların uzun dönem takiplerinin gerekli olduğunu ve metastatik durumda sistemik kemoterapinin çok etkili olabileceğini vurgulamaktadır.

Anahtar Kelimeler: Kemoterapi, Metastaz, Paratestiküler leiomyosarkoma

\begin{abstract}
Scrotal leiomyosarcoma is seen rarely and may be paratesticular or intratesticular. An 18-year-old male, operated for paratesticular leiomyosarcoma 2 years before, was referred to our department with unresectable intraabdominal metastases. Combination chemotherapy regimen (ifosfamide with mesna protection and doxorubicin) was started and very good partial regression was achieved after 6 cycles. Our case highlighted that long-term follow-up of the patients with the paratesticular leiomyosarcoma is required and systemic chemotherapy might be very effective in metastatic setting.
\end{abstract}

Keywords:Chemotherapy, Metastasis, Paratesticular leiomyosarcoma

\section{Introduction:}

Leimyosarcomas are malignant soft tissue sarcomas arising anywhere from tissues containing smooth muscle. Scrotal leiomyosarcomas are seen rarely and may be paratesticular or intratesticular (1). Radical orchiectomy is standart treatment procedure and definitive diagnosis is made by histological examination of orchiectomy material, radiation therapy may be useful for locoregional microscopic disease $(2,3)$. The role of chemotherapy is not well known. We report a patient with metastatic paratesticular leiomyosarcoma with very good response to palliative chemotherapy.

\section{Case Report:}

A 18 year-old man was referred to hospital with 2 week history of painless scrotal mass. He had no remarkable constitutional symptom. His pastmedical history was unremarkable except that he had a history of trauma of electrical shock 1 month ago. Physical examination revealed $6 \times 5 \mathrm{~cm}$ hard mass in left scrotum. Ultrasound scan of scrotum showed normal right and left testis and well circumscribed lesion with heterogeneous echogenicity on the left paratesticular region. Complete blood count, $\alpha$-feto protein level, beta human chorionic gonadotropin level and biochemistry parameters were normal, except that lactate dehydrogenase level 578U/L (range 95-500). There was no metastasis on 
chest and abdominal computerized tomography (CT) scans. A left radical orchiectomy was performed. Pathological examination of orchiectomy specimen was reported as leiomyosarcoma of paratesticular region. Macroscopically tumor was yellowishwhite, fibriller, solid and $6 \times 5 \times 5 \mathrm{~cm}$ in size, it was seperated from left testis by a fibrous capsule. The tumor did not involve spermatic funiculus, but epididymis was infiltrated by the tumor. There was plenty of mitosis and immunohistochemical staining revealed that the tumor was positive for smooth muscle actin. After orchiectomy there was no adjuvant treatment and follow up visit. Two years later, the patient was referred to our hospital with the complaint of abdominal pain for 2 months. Physical examination revealed a $15 \times 12 \mathrm{~cm}$ hard mass extending from epigastrium and left upper abdomen to the umbilicus. Abdominal magnetic resonans imaging showed a 19x12cm lobulated-septated kistic lesion, on left upper abdomen, pushig spleen, stomach, pancreas, vena cava inferior, superior mesenteric vasculature, splenic vein, transverse colon, left ureter, extending to paraaortic, aortocaval region. He underwent surgery. On surgical exploration, there was a mass, $25 \times 20 \mathrm{~cm}$ in size, growing from retroperitoneal reigon; covering all abdominal main vasculature and descending colon; infiltrating intestinal structure, stomach, peripancreatic tissue and spleen. Complete surgical excision was impossible; partial colon resection, splenectomy, left nefrectomy, distal pancreatectomy and mass excision was done. There was gross residual mass on paraaortic, paracaval region. Pathological examination of resected material revealed leiomyosarcoma, with plenty of atypical mitosis, high grade tumor; on immunhistochemical staining desmin, vimentin and HHF 35 was positive. Postoperatively, abdominal computerized tomography showed a mass, $13 \times 9 \mathrm{~cm}$ in size, with somewhat similar feature to that of preoperative imaging (Figure 1). The chemotherapy regimen used for other soft tissue sarcomas was started: Ifosfamide $1800 \mathrm{mg} / \mathrm{m} 2 /$ day on day $1-4$ with mesna uroprotection and doxorubicin $60 \mathrm{mg} / \mathrm{m} 2 /$ day on day 1 , to be repeated every 3 weeks.

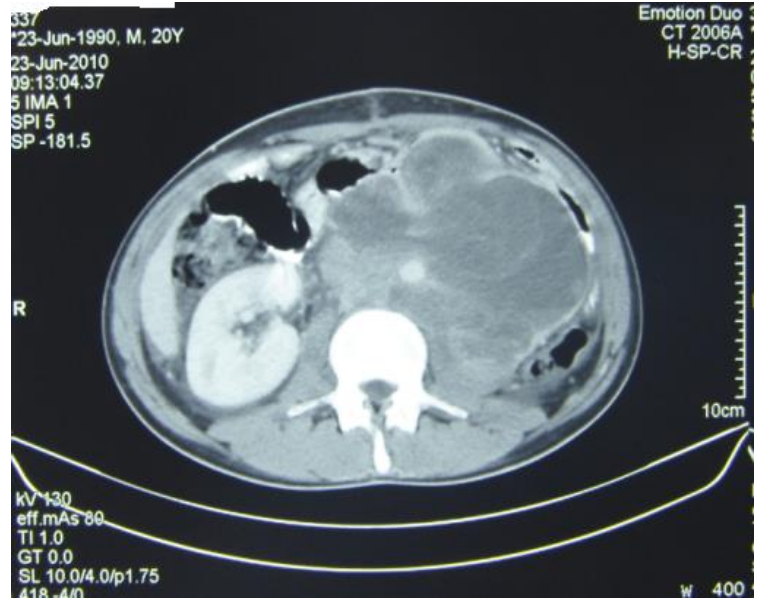

Figure 1. Abdominal computerized tomography taken postoperatively, showed a mass, $13 \times 9 \mathrm{~cm}$ in size.

After first cycle of chemotherapy, febril neutropenia episode and deterioration of renal function was developed, following cycles were given with dose reduction and with support of granulocyte-colony stimulating factor. Even during second cycle, there was evident symptomatic relief and regression in size of abdominal mass on physical examination. After 6 cycles of chemotherapy, there was very good partial regression on abdominal imaging (Figure 2). Two more cycles of same chemotherapy regimen was planned, but because of deterioration of renal function 2 cycles of doxorubicin $(60 \mathrm{mg} / \mathrm{m} 2 /$ day on day 1$)$ and vincristin ( $2 \mathrm{mg} /$ day on day 1$)$ per 3 weeks were given. After completion of chemotherapy, abdominal MRI showed only a few parailiac and paraaortical lymph nodes, the largest lymh node was $18 \times 10 \mathrm{~mm}$ in size and a parauretral glandular cyst on right iscioanal fossa. The patient continiues followup visits for 45 months and on the last abdominal MRI, there is only parauretral gland cyst on right iscioanal fossa and there is no lymph node greater than $1 \mathrm{~cm}$ in size, but he is suffering from renal failure. 


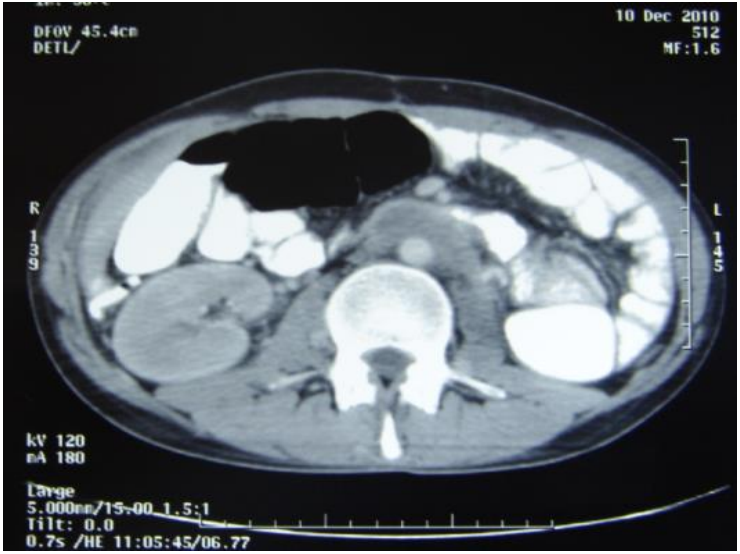

Figure 2. Abdominal computerized tomography taken after 6 cycles of chemotherapy, showed very good partial regression.

\section{Discussion:}

Primary leiomyosarcoma of paratesticular region is seen rarely. In a series of 1583 adult soft tissue sarcomas, 14 patients $(0.8 \%)$ had paratesticular sarcoma, 4 patients $(0.25 \%)$ were paratesticular leiomyosarcomas, 5 rhabdomyosarcomas, 3 liposarcomas, 1 malignant fibrous histiocytoma, 1 undifferentiated sarcoma (1). In another study, histological subtypes of 7 adult paratesticular sarcomas were 2 leiomyosarcomas, 2 differentiated liposarcoma, 2 low-grade fibromyxoid sarcoma and one case undifferentiated pleomorphic sarcoma (4). In some studies, peak incidence of paratesticular leiomyosarcoma was in sixty and seventy decades $(5,6)$. Leiomyosarcomas may arise from the spermatic cord, from the dartous layer of scrotum or from the epididymis. Most of

\section{References:}

1. Russo P. Urologic sarcoma in adults. Urol Clin North Am. 1991 18:581-7.

2. Fagundes MA, Zietman AL, Althausen AF, Coen JJ, Shipley WU. The management of spermatic cord sarcoma. Cancer. 1996;77:1873-6.

3. Catton CN, Cummings BJ, Fornasier V, O'Sullivan B, Quirt I, Warr D. Adult paratesticular sarcomas: a review of 21 cases. J Urol. 1991;146:342-5.

4. Unlu Y, Huq GE, Ozyalvacli $G$, et al. Paratesticular sarcomas: A report of seven cases. OncolLett. 2015 Jan;9(1):308-312.

5. Russo P, Brady MS, Conlon K, et al. Adult urological sarcoma. J Urol. 1992;147:1032-6.

6. Fisher C, Goldblum JR, Epstein JI, Montgomery E. Leiomyosarcoma of paratesticular region. A paratesticular leiomyosarcoma arise from soft tissues of spermatic cord (80-90\%), originating from epididymis is seen rarely $(3,7)$.

Because of low prevalence of this disease, there is limited knowledge about clinical course and management. The clinical course of paratesticular leiomyosarcomas determined by site, size, grade and evidence of metastasis $(8,9)$. High grade tumors behave aggresively (10). Radical orchiectomy is the standart primary surgical procedure and adjuvant radiation therapy may be effective in controling loco-regional recurrence $(2,3,9)$. About adjuvant or palliative systemic chemotherapy, there is data only from soft tissue sarcomas at other sites of body, doxorubicin-based chemotherapy may be effective, but effect on overall survival is not shown (11). Our patient had grade 3 tumor, no adjuvant chemotherapy and no radiation therapy was given. Two years later, intraabdominal metastasis was developed and very good response was obtained from systemic chemotherapy regimen (doxorubicin and ifosfamide) also used for soft tissue sarcomas at other sites of body. As in our case, the clinician should be aware of nephrotoxicity during chemotherapy period, especially in patient with solitary kidney. In conclusion, paratesticular leiomyosarcoma is a rare disease, radical orchiectomy is accepted primary surgical treatment, adjuvant radiation therapy may be considered for controlling loco-regional microscopic disease. Due to the risk of recurrence long-term follow-up is required especially for high grade tumors, and for metastatic disease, systemic chemotherapy may be very effective.

clinicopathologic study. Am J Surg Pathol. 2001;25:1143-9.

7. Varzaneh FE, Verghese M, Shmooker BM: Paratesticular leiomyosarcoma in an elderly man. Urology. 2002;60:1112.

8. Folpe AL, Weiss SW. Paratesticular soft tissue neoplasms.Semin Diagn Pathol. 2000;17:307-18.

9. Haran S, Balakrishan V, Neerhut G. A Rare Case of Paratesticular Leiomyosarcoma. Case Rep Urol. 2014;2014:715395.

10. Catton C, Jewett M, O'Sullivan B, Kandel R. Paratesticularsarcoma: failure patterns after definitive local therapy. J Urol. 1999;161:1844-7.

11. Tierney JF, Stewart LA, Parmar MKB. Adjuvant chemotherapy for localised resectable soft-tissue 
sarcoma of adults: meta-analysis of individual data.

Lancet. 1997;350:1647-54. 